\title{
Purification of the Catalytically Active Phosphorylated Form of Insulin Receptor Kinase by Affinity Chromatography with O-Phosphotyrosyl-Binding Antibodies ${ }^{1}$
}

\author{
DENNIS T. PANG, ${ }^{2}$ BALDEV R. SHARMA, AND JULES A. SHAFER ${ }^{3}$
}

Department of Biological Chemistry, University of Michigan Medical School, Ann Arbor, Michigan 48109

Received February 13, 1985, and in revised form June 18, 1985

The catalytically active, tyrosyl-phosphorylated form of insulin receptor kinase was isolated from human placenta by a procedure which exploits the propensity for the intact $\alpha_{2} \beta_{2}$ form of insulin receptor to undergo insulin-promoted autophosphorylation at tyrosyl residues and concomitant activation as a tyrosyl kinase. Purification of tyrosylphosphorylated insulin receptor was effected by adsorption on and elution (with a hapten) from a column of $O$-phosphotyrosyl-binding antibody immobilized on protein A-Sepharose (Ab-protein $\mathrm{A})$. The starting material for the purification process was protein which had been solubilized from placental membranes and purified by chromatography on immobilized wheat germ agglutinin. After chromatography on Ab-protein A to remove preexisting $O$-phosphotyrosyl-containing proteins, the fraction which did not adsorb to the Ab-protein A column was incubated with insulin and briefly treated with ATP so as to maximize selective autophosphorylation of insulin receptor. This material was then subjected to chromatography on $\mathrm{Ab}$-protein $\mathrm{A}$. Although the amount of the intact $\alpha_{2} \beta_{2}$ form of insulin receptor present in the starting material was only a small fraction of the protein $(\sim 0.2 \%)$ and only $\sim 20 \%$ of the insulin-binding forms of the receptor present, it was eluted (with $10 \mathrm{~mm} p$-nitrophenyl phosphate) from the column in $\geqslant 80 \%$ purity. Chromatography on Ab-protein A appears to have an advantage over the alternative affinity chromatographic procedures which utilize immobilized insulin or antiinsulin receptor antibody to adsorb insulin receptor, since these procedures do not resolve the intact $\alpha_{2} \beta_{2}$ form of insulin receptor from the nicked insulin-binding forms of the receptor which do not undergo insulin promoted autophosphorylation. (c) 1985 Academic Press, Inc.

Several procedures have been published recently for purifying insulin receptor via affinity chromatography on immobilized insulin or immobilized receptor antibody [e.g., (1-8)]. These procedures, however, do not appear to yield homogeneous active in-

\footnotetext{
${ }^{1}$ This study was supported in part by Grants AM 27659 and AM35249 from the United States Public Health Service.

${ }^{2}$ Part of this work is described in a Ph.D. dissertation submitted to the Graduate School of The University of Michigan.

${ }^{3}$ To whom correspondence should be addressed.
}

sulin receptor. A major difficulty is that the existing purification procedures based upon aftinity chromatography do not resolve the various insulin-binding forms of the receptor. Limited proteolysis of the $\beta$ subunits of the intact $\alpha_{2} \beta_{2}$ tetrameric receptor results in at least two additional insulin-binding forms of the receptor, $\alpha_{2} \beta \beta_{1}$, and $\alpha_{2}\left(\beta_{1}\right)_{2}(9)$. These forms, together with others, have been shown to be present after affinity chromatography, on immobilized insulin (7), of insulin receptor from human placenta which had been partially purified by chromatography on wheat germ agglu- 
tinin (WGA). ${ }^{4}$ In our hands (10), only $\sim 20 \%$ of the insulin-binding forms of insulin receptor is present as the intact $\alpha_{2} \beta_{2}$ tetrameric receptor in preparations of WGA-purified insulin receptor from human placenta. Since affinity chromatography on immobilized insulin would not be expected to separate the insulin-binding forms of insulin receptor, it is not surprising that a highly heterogeneous mixture of insulin receptor is obtained by this method. The presence of multiple forms of the receptor could complicate studies of its competence to function as a protein kinase, since only the intact $\alpha_{2} \beta_{2}$ form of the receptor undergoes the insulin-mediated autophosphorylation reaction $(10,11)$ which induces the tyrosyl kinase activity of insulin receptor. These considerations underscored the need for an alternative procedure for purification of insulin receptor, and prompted us to develop a procedure for isolating the intact $\alpha_{2} \beta_{2}$ form of insulin receptor which exploits the unique ability of the $\alpha_{2} \beta_{2}$ form to undergo autophosphorylation. The procedure which is disclosed in this work involves adsorption (and specific elution with hapten) of phosphorylated insulin receptor on an immobilized antibody which binds $O$-phosphotyrosyl residues.

\section{MATERIALS AND METHODS}

Materials. Histone $\mathrm{H} 2 \mathrm{~b}$ was obtained from Worthington; $\left[\gamma^{32}\right.$ P]ATP was from Amersham; keyhole limpet hemocyanin (KLH) was from CalbiochemBehring; Angiotensin II and protein A-Sepharose were from Sigma; antireceptor antiserum was a generous gift from Dr. C. Ronald Kahn; and $N, N^{\prime}$-diace-

\footnotetext{
${ }^{4}$ Abbreviations used: KLH, keyhole limpet hemocyanin; Ab-protein A, $O$-phosphotyrosyl binding antibody immobilized on protein A-Sepharose; BSA, bovine serum albumin; Mes, 4-morpholineethanesulfonic acid; SDS, sodium dodecyl sulfate; SDS-PAGE, polyacrylamide gel electrophoresis done in the presence of SDS; DTT, dithiothreitol; WGA, wheat germ agglutinin; Hepes, 4-(2-hydroxyethyl)-1-piperazineethanesulfonic acid; PBS, phosphate-buffered saline; GAR-HRP, goat anti-rabbit-horseradish peroxidase; PTC, phenylisothiocyanate; HT, Hepes-Triton buffer; KT, potassium phosphate-Triton buffer; TCA, trichloroacetic acid.
}

tylchitobiose was generously supplied by Dr. Irwin Goldstein.

$N$-Bromoacetyl-O-phosphotyramine. This was prepared using a modification of a procedure described by Hartman (12) for bromoacetylating $O$-phosphoethanolamine. $O$-Phosphotyramine $(1 \mathrm{~g}, 4.6 \mathrm{mmol})$, prepared according to published procedures $(13,14)$, was dissolved in $20 \mathrm{ml}$ of water and sufficient $5 \mathrm{M} \mathrm{LiOH}$ to bring the $\mathrm{pH}$ to 8.5 . The resulting solution was stirred in a cooling bath $\left(20^{\circ} \mathrm{C}\right)$, and bromoacetyl bromide ( $8.8 \mathrm{~g}, 43.6 \mathrm{mmol})$ was added dropwise while maintaining the $\mathrm{pH}$ of the reaction mixture between 7.5 and 8.5 by addition of $5 \mathrm{M} \mathrm{LiOH}$. The clear solution was filtered, and evaporated to dryness under reduced pressure at $25^{\circ} \mathrm{C}$. The resulting residue was macerated with ether $(20 \mathrm{ml}, 3 \times)$ followed by ethanol $(40 \mathrm{ml}, 3 \times)$, and was filtered each time to yield a residue $(600 \mathrm{mg})$ of $\mathrm{N}$-bromoacetyl-O-phosphotyramine dilithium salt. TLC (silica gel; $n$-BuOH:HAc: $\mathrm{H}_{2} \mathrm{O}, 7: 2.5$ ) indicated one spot with an $R_{f}$ of 0.49 . The product was negative in a trinitrobenzenesulfonic acid test for primary amines (15), and contained no free phenolic groups as judged by the similar uv spectra obtained in water at $\mathrm{pH} 7$ and 12.

O-Phosphotyramine-KLH conjugate. N-Bromoacetyl-O-phosphotyramine dilithium salt (350 $\mathrm{mg}, 1$ mmol) was added in small lots to $27.5 \mathrm{mg}$ of KLH in

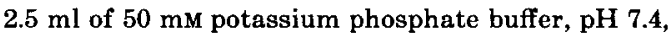
$0.15 \mathrm{M} \mathrm{NaCl}$ (PBS). During the addition and for $96 \mathrm{~h}$ thereafter, the $\mathrm{pH}$ was maintained at 9.0-9.5 by addition of $1 \mathrm{M} \mathrm{LiOH}$. The reaction was terminated by subjecting the turbid reaction mixture to dialysis against PBS. The clear solution of KLH conjugate obtained after six changes of dialyzate was analyzed by uv spectrophotometry. The analysis, which indicated an incorporation of $4.1 O$-phosphotyramine residues per 100 aminoacyl residues of KLH, was carried out using

$$
\begin{aligned}
{[\mathrm{H}] } & =\frac{\left(A_{\lambda 2}\right)_{o}-\left(A_{\lambda 3}\right)_{o} \frac{\left(A_{\lambda 1}\right)_{p}}{\left(A_{\lambda 3}\right)_{p}}}{\left(\epsilon_{\lambda 1}\right)_{h}} \\
{[\mathrm{C}] } & =\frac{\left(A_{\lambda 3}\right)_{c} \frac{\left(A_{\lambda 2}\right)_{p}}{\left(A_{\lambda 3}\right)_{p}}}{\left(\epsilon_{1 \mathrm{~cm}}^{0.1 \% 2} \lambda 2\right)_{p}} \\
I & =\frac{[\mathrm{H}] \times 10^{4}}{[\mathrm{C}]}
\end{aligned}
$$

$A_{\lambda 1}, A_{\lambda 2}$, and $A_{\lambda 3}$ denote absorbance at $\lambda 1, \lambda 2$, and $\lambda 3$. The subscripts $c, p$, and $h$ denote conjugated protein, unmodified protein, and hapten model compound ( $N$ bromoacetyl- $O$-phosphotyramine), respectively. $[\mathrm{H}]$ and $[\mathrm{C}]$ indicate the molar concentration of proteinlinked haptenic groups and the concentration of protein conjugate (in $\mathrm{mg} / \mathrm{ml}$ ), respectively. $I$ is the incorporation of hapten residues per 100 aminoacyl residues of protein assuming an average equivalent 
weight of 100 for an aminoacyl residue. Values of 268 $\mathrm{nm}, 280 \mathrm{~nm}, 290 \mathrm{~nm}$, and $783 \mathrm{~cm}^{-1} \mathrm{M}^{-1}$ were used for the $\lambda 1, \lambda 2, \lambda 3$, and $(\epsilon \lambda 1)_{h}$, respectively. The values of $\left(A_{\lambda 1}\right)_{p} /\left(A_{\lambda 3}\right)_{p},\left(A_{\lambda 2}\right)_{p} /\left(A_{\lambda 8}\right)_{p}$, and $\epsilon_{1 \mathrm{~cm}}^{0.1 \%} \lambda 2$ were $1.23,1.45$, and 1.77. Determination of incorporation $(I)$ using Eqs. [1]-[3] is based upon the assumption that the spectrum of the hapten is not perturbed by conjugation to the protein and the observation that at $\lambda 3$ the contribution of the haptenic group to the absorbance is negligible relative to that of the protein.

O-Phosphotyramine-BSA conjugate. This was prepared by reaction of $40 \mathrm{mg}$ of BSA, dissolved in $2 \mathrm{ml}$ of PBS, with $N$-bromoacetyl- $O$-phosphotyramine ( 350 $\mathrm{mg}, 1 \mathrm{mmol}$ ) as described for the preparation of the KLH conjugate.

Preparation of antisera. Antibody which binds $O$ phosphotyrosyl residues was raised in New Zealand white rabbits using the immunization procedure of Ross et al. (13) with the KLH conjugate of $N$-bromoacetyl- $O$-phosphotyramine as antigen. The titer of the test antiserum was determined by an immunodotblotting peroxidase assay using a goat anti-rahbithorseradish peroxidase (GAR-HRP) conjugate as the second antibody (16). Antiserum to the KLH-phosphotyramine conjugate was tested for hapten specificity against the BSA-phosphotyramine conjugate (3 ng) adsorbed on nitrocellulose membranes using a BioRad GAR-HRP assay kit. The suggested protocol was modified in that $0.05 \%$ Tween 20 in $20 \mathrm{mM}$ Tris, $0.5 \mathrm{M}$ $\mathrm{NaCl}, \mathrm{pH} 7.5$ (TBS) was used in the blocking and antibody buffer instead of the gelatin-TBS solutions. Additionally, $0.1 \mathrm{~m}$ Mes buffer, $\mathrm{pH}$ 6.0, was used instead of TBS for buffering the peroxidase-catalyzed reaction. Dilutions of antisera of $1 / 500$ through $1 / 50,000$ were tested for their ability to react with antigen. Antisera with titers in excess of $1 / 25,000$ were used for preparation of antibody.

O-Phosphotyramine-Sepharose. Sepharose 4B (10 ml packed gel) was activated with $\mathrm{CNBr}$ by the method of March et al. (17), and coupled to $O$-phosphotyramine using a modification of the procedure of Ross et al. (13). The activated slurry was filtered to a moist cake, and then transferred to a plastic bottle containing $217 \mathrm{mg}$ ( $1 \mathrm{mmol}$ ) $O$-phosphotyramine which had been dissolved in $10 \mathrm{ml}$ of $0.1 \mathrm{M} \mathrm{NaHCO}_{3}$ and adjusted to pH 9.5 with $1 \mathrm{~m} \mathrm{NaOH}$. The reaction mixture was gently shaken at $4^{\circ} \mathrm{C}$ for $20 \mathrm{~h}$ and filtered. The resulting gel was transferred to $20 \mathrm{ml}$ of $0.5 \mathrm{M}$ glycine (pH 8.0) and shaken at $4{ }^{\circ} \mathrm{C}$ for an additional $10 \mathrm{~h}$. It was then filtered and washed according to the procedure of March et al. (17). The washed gel was transferred to a column, washed with water (until the washing showed no absorbance at $268 \mathrm{~nm}$ ), and stored at $4^{\circ} \mathrm{C}$.

Determination of gel-linked $O$-phosphotyramine. The gel was hydrolyzed according to the method of Martensen (18) for liberating phosphotyrosine from proteins. The supernatant solution obtained after neu- tralization of the $\mathrm{KOH}$ with $\mathrm{HClO}_{4}$ was treated with phenylisothiocyanate (PTC). The resulting PTC derivative of $O$-phosphotyramine was quantified by high performance liquid chromatography (10) using PTC$O$-phosphotyramine prepared from known amounts of $O$-phosphotyramine as standards. The $O$-phosphotyramine content of the gel was thus found to be 1.05 $\mu \mathrm{mol} / \mathrm{ml}$.

Purification of $O$-phosphotyrosyl binding antibody. Antiserum ( $49 \mathrm{ml}$ ) was adjusted to $50 \mathrm{~mm}$ sodium fluoride and $0.1 \mathrm{mM}$ sodium vanadate by addition of the solid compounds. After standing at $4^{\circ} \mathrm{C}$ for $30 \mathrm{~min}$ the serum was centrifuged and the supernatant solution was applied to a $4.5 \times 1.5 \mathrm{~cm}$ column of $O$ phosphotyramine-Sepharose which had been equilibrated at $4^{\circ} \mathrm{C}$ with $0.15 \mathrm{M} \mathrm{NaCl}, 10 \mathrm{~mm}$ potassium phosphate, $\mathrm{pH}$ 7.4. The column was washed successively with $20 \mathrm{ml}$ of $0.2 \mathrm{M} \mathrm{KCl}, 10 \mathrm{mM}$ potassium phosphate buffer, $\mathrm{pH} 7.4 ; 20 \mathrm{ml}$ of $0.2 \mathrm{M}$ potassium phosphate, $\mathrm{pH} \mathrm{7.4}$; and $20 \mathrm{ml}$ of $50 \mathrm{~mm}$ Hepes buffer, $\mathrm{pH}$ 7.6. Antibody was eluted $(0.4 \mathrm{ml} / \mathrm{min})$ from the column with $20 \mathrm{ml}$ of $0.2 \mathrm{M} p$-nitrophenyl phosphate in $50 \mathrm{mM}$ Hepes buffer (final pH, 7.4). The eluate was collected in $1-\mathrm{ml}$ fractions, and those fractions containing $>0.4$ $\mathrm{mg}$ protein $/ \mathrm{ml}$ were combined. The pooled solution of antibody was then dialyzed against four 1-liter portions of $50 \mathrm{mM} \mathrm{NaCl}$ to remove the $p$-nitrophenyl phosphate and yield $14 \mathrm{ml}$ of solution containing 0.80 $\mathrm{mg} / \mathrm{ml}$ protein. The $O$-phosphotyramine-Sepharose, which could be used repeatedly, was equilibrated with $0.1 \mathrm{M}$ potassium phosphate $\mathrm{pH} 7.4,0.02 \%$ sodium azide, and stored at $4^{\circ} \mathrm{C}$.

Immobilization of O-phosphotyrosyl binding antibody on protein A-Sepharose. A protein A-Sepharose column $(3 \mathrm{ml}, 3.9 \times 1.0 \mathrm{~cm})$ was equilibrated with $50 \mathrm{mM}$ Hepes, pH 7.6, 0.1\% Triton X-100 (HT), and $0.9 \mathrm{ml}$ of the solution of purified antibody $(0.8 \mathrm{mg} / \mathrm{ml})$ was applied to the column. After the antibody solution ran down to the top of the gel, the flow was stopped and the column was left al room temperature for 45 min. The resulting Ab-protein A column was washed with $15 \mathrm{ml}$ of $0.2 \mathrm{M}$ potassium phosphate, $\mathrm{pH} 7.5,0.1 \%$ Triton $\mathrm{X}-100(\mathrm{KT})$, equilibrated with $0.02 \%$ sodium azide, and stored at $4^{\circ} \mathrm{C}$.

Purification of phosphorylated insulin receptor. Insulin receptor was isolated from human placenta and partially purified by chromatography on immobilized WGA as previously described $(3,19)$. To remove preexisting phosphotyrosyl-containing proteins, the eluate from WGA-agarose $(27 \mathrm{ml}, 1 \mathrm{mg} / \mathrm{ml}$ protein from 1.5 human placentas) was passed (at $4^{\circ} \mathrm{C}$ ) through a 3-ml column of Ab-protein A, which had been previously washed with $15 \mathrm{ml}$ of $\mathrm{KT}$ and equilibrated with HT. The column was then washed with $3 \mathrm{ml} \mathrm{HT}$ and the wash was combined with the flowthrough.

The resulting solution was mixed with $0.3 \mathrm{ml}$ of 10 $\mu \mathrm{M}$ insulin and $75 \mu \mathrm{l}$ of $2 \mathrm{M} \mathrm{MnCl}_{2}$, and then incubated 
for $30 \mathrm{~min}$ at room temperature. Autophosphorylation was initiated by the addition of $75 \mu \mathrm{l}$ of $20 \mathrm{mM} \mathrm{ATP}$, and was terminated after $5 \mathrm{~min}$ by addition of $1.2 \mathrm{ml}$ of $0.25 \mathrm{M}$ EDTA, $\mathrm{pH} 7.6$, and $56 \mathrm{mg} \mathrm{NaF}$. The reaction mixture was then cooled in an ice bath, and passed through a $1-\mathrm{ml}$ Ab-protein $\mathrm{A}$ column at $4^{\circ} \mathrm{C}$ which had been washed with KT and equilibrated with HT. The column was then washed with $10 \mathrm{ml}$ of $0.15 \mathrm{M}$ $\mathrm{NaCl}$ in HT. After a wash with $10 \mathrm{ml} \mathrm{HT}$, the column was eluted with $4 \mathrm{ml}$ of $10 \mathrm{~mm} p$-nitrophenyl phosphate in HT. The first $0.5 \mathrm{ml}$ of eluate contained no receptor and was discarded. The remainder of eluate which contained insulin receptor was collected. The Ab-protein A column was regenerated by washing with KT. No apparent change in the capacity was observed after it had been used more than ten times. During the purification procedure care was taken to prevent solutions of the receptor from contacting metals, since this can result in a large decrease in the activity of the receptor. [The inhibition of the receptor kinase by metal ions is described in Ref. (20).] Addition of 1 mM DTT to the wash and elution buffers did not affect the specific kinase activity of the purified receptor.

Protein assays. Bio-Rad protein assay dye reagent (21) was used for the estimation of protein in the WGA-purified receptor and in affinity-purified $O$ phosphotyrosyl binding antibody, with ovalbumin and rabbit IgG as the protein standards, respectively. For estimation of protein content in the Ab-protein ASepharose eluate, a Zeineh soft laser scanning densitometer (Biomed Instruments, Inc., Model S1-TRFF) was used for density measurements of the 95- and $125-\mathrm{kDa}$ bands in the silver-stained gels which were developed according to the method of Morrissey (22). The protein content in these two bands was estimated from a linear standard curve relating density to protein content; the standard curve was prepared using ovalbumin (50-400 ng) as the reference standard.

Assays of kinase activity. Two kinase assay procedures, with both histone $\mathrm{H} 2 \mathrm{~b}$ and angiotensin II as substrates, were used to determine the activity of the receptor at different stages of purification. In assay $\mathrm{I}$, a sample of receptor in $10 \mu \mathrm{l}$ was adjusted to a volume of $70 \mu \mathrm{l}$ so as to contain $0.71 \mu \mathrm{M}$ insulin, $0.43 \mathrm{mg} /$ $\mathrm{ml}$ histone $\mathrm{H} 2 \mathrm{~b}, 28.6 \mathrm{~mm}$ Hepes, $\mathrm{pH} 7.6,0.057 \%$ Triton $\mathrm{X}-100$, and $5.7 \mathrm{mM} \mathrm{MnCl}$. In the case of phosphorylated, WGA-purified receptor, $1.4 \mathrm{mM} p$-nitrophenyl phosphate was included. This was done so that the conditions of the assays of the antibody-purified and WGA-purified receptor would be similar. Separate studies indicated that the $1.4 \mathrm{~mm} p$-nitrophenyl phosphate had no substantial effect on the assay. Insulin was included in all assays unless otherwise indicated. After a 10 -min incubation at room temperature, phosphorylation was initiated by addition of $10 \mu \mathrm{l}$ of $0.2 \mathrm{mM}\left[\gamma^{-32} \mathrm{P}\right] \mathrm{ATP}$ (sp act, $2000-4000 \mathrm{cpm} / \mathrm{pmol}$ ). Phosphorylation was allowed to proceed for $15 \mathrm{~min}$ at room temperature $\left(23-25^{\circ} \mathrm{C}\right)$, whereupon the re- action was quenched by heating with SDS sample buffer, and subjected to SDS-PAGE with an $11.3 \%$ separation gel. After staining, destaining, and drying, the histone bands were excised from the dried gel and counted by the Cerenkov method. When angiotensin II was used as substrate, $2.9 \mathrm{~mm}$ angiotensin was used in place of the $0.43 \mathrm{mg} / \mathrm{ml}$ histone $\mathrm{H} 2 \mathrm{~b}$. After the reaction was quenched by addition of $25 \mu 120 \%$ TCA, the phosphorylated peptide was absorbed on phosphocellulose paper and quantified as described by Staudtmauer and Rosen (23).

Assay II was also used for determination of the kinase activity of the receptor purified by chromatography on Ab-protein A. It was identical to assay I described above except that $10 \mu$ of the eluate from the $\mathrm{Ab}$-protein A column was assayed in the presence of $10 \mu \mathrm{l}$ phosphorylated, WGA-purified receptor. The activity of the receptor in the eluate was obtained by subtracting from the total activity the contribution from the WGA-purified receptor determined in the presence of $p$-nitrophenyl phosphate.

Immunoprecipitation of insulin receptor. A solution of insulin receptor in HT $(50 \mu \mathrm{l})$ was mixed with 0.5 $\mu \mathrm{l}$ B-9 antireceptor antiserum. After a 2-h incubation at $4^{\circ} \mathrm{C}, 20 \mu \mathrm{l}$ of a $50 \%$ suspension of protein $\mathrm{A}-\mathrm{Se}-$ pharose in HT was added to the mixture, and the resulting suspension was shaken on a rotatory shaker for $2 \mathrm{~h}$ at $4^{\circ} \mathrm{C}$. The suspension was then centrifuged and the supernatant solution was removed. The remaining pellet was washed twice with $0.5 \mathrm{ml}$ of 0.15 $\mathrm{M} \mathrm{NaCl}$ in HT and once with $0.5 \mathrm{ml} \mathrm{HT}$. For analyses wherein the kinase activity was to be determined, 10 $\mu$ l of supernatant solution or the entire pellet were used as samples in assay $\mathrm{I}$ with histone $\mathrm{H} 2 \mathrm{~b}$ as substrate. In analyses wherein ${ }^{32} \mathrm{P}$-labeled receptor was to be determined, the entire supernatant and the entire pellet from the immunoprecipitation were separately adjusted to a volume of $80 \mu \mathrm{l}$ with water after addition of $20 \mu$ l of a fourfold concentrated SDS sample buffer of Laemmli (24) but without thiol. Samples of these solutions $(50 \mu \mathrm{l})$ were subjected to SDS-PAGE with a $4.5 \%$ separation gel.

$S D S-P A G E$. This was performed as described by Laemmli (24). For nonreduced receptor, a $4.5 \%$ separation gel with acrylamide and $N, N^{\prime}$-methylenebisacrylamide in a ratio of 100:1 was used. For reduced receptor and kinase assays with histone $\mathrm{H} 2 \mathrm{~b}$ as substrate, 7.5 and $11.3 \%$ gels were used, respectively, with acrylamide and $N, N^{\prime}$-methylenebisacrylamide in a ratio of $30: 0.8$.

Other procedures. Iodination of insulin, crosslinking of insulin receptor with ${ }^{125} \mathrm{I}$-insulin, and other procedures were carried out as described previously $(10,19)$.

\section{RESULTS AND DISCUSSION}

Insulin receptor from human placental tissue was solubilized and partially purified 
by lectin chromatography on immobilized WGA. The WGA-purified receptor was then passed through a column of $O$-phosphotyrosyl binding antibody immobilized on protein A-Sepharose to remove preexisting phosphotyrosyl-containing proteins. The fraction which did not bind to the column was incubated with insulin and treated briefly with ATP to effect specific autophosphorylation of the insulin receptor. This reaction mixture was applied to a column of immobilized $O$-phosphotyrosyl-binding antibody. After washing the column, phosphorylated insulin receptor was eluted with $10 \mathrm{mM} p$-nitrophenyl phosphate (Fig. 1).

The feasibility of using antibodies reactive toward the phenyl phosphate group for purification of $O$-phosphotyrosyl-containing proteins was first demonstrated by Ross et al. (13), who used such antibodies in the purification of $O$-phosphotyrosylcontaining proteins from virally transformed cells. Our application of this approach to the purification of the insulin receptor involved some important modifications, however. The antibodies were raised using as antigen a KLH conjugate of $N$-bromocetyl- $O$-phosphotyramine rather than the KLH conjugate of $p$-azobenzyl phosphonate used by Ross et al. (13), since, as indicated by Ross et al. (13), the use of an antigen closer in structure to an $O$-phosphotyrosyl residue than $p$-azobenzyl phosphonate would be expected to yield antibody with a higher affinity for $O$-phosphotyrosyl residues in proteins. To further enrich our antibody preparation in antibodies with a high affinity for $O$-phosphotyrosyl residues, we used $0.2 \mathrm{M}$ (rather than $10 \mathrm{~mm}$ ) phosphate buffer to wash antibody which was bound to $O$-phosphotyrosineSepharose during purification of the antibody by affinity chromatography. Although this higher concentration of phosphate removed weakly binding antibody, the phosphate grouping was still a major determinant of the antibody-hapten interaction. Thus, high concentrations of phosphate buffer $(0.2 \mathrm{M})$ could elute insulin receptor from the immobilized purified antibody (data not shown). Finally, rather than immobilizing the purified antibody by linking
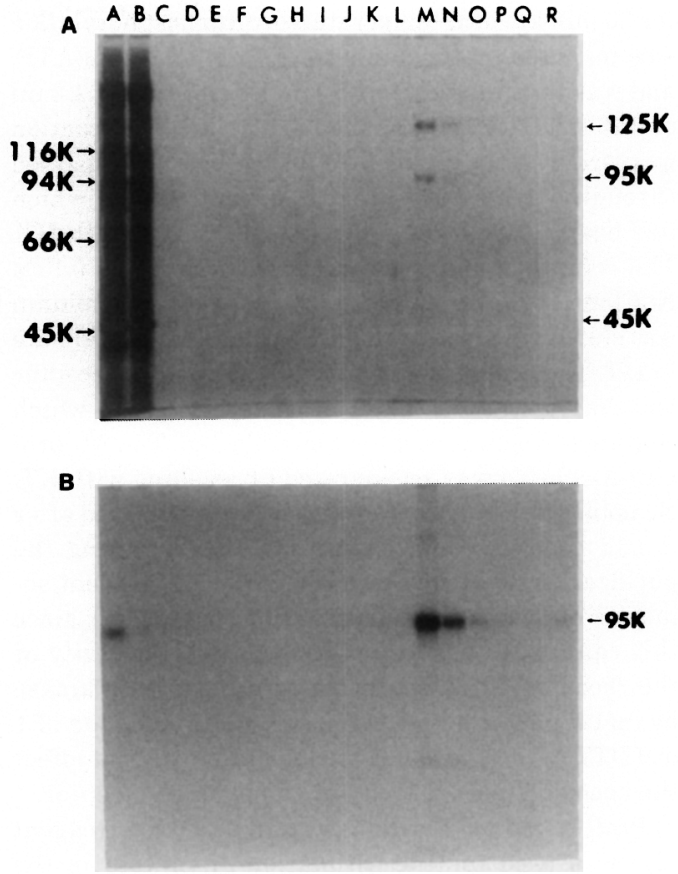

FIG. 1. Specific elution of autophosphorylated insulin receptor from immobilized 0 -phosphotyrosyl-binding antibody. Autophosphorylated (with $\left[\gamma^{-} \mathrm{P} P\right] \mathrm{ATP}$ ) insulin receptor from 1.5 placentas in $20 \mathrm{ml}$ was subjected to chromatography on immobilized $O$-phosphotyrosyl-binding antibody. Samples $(40 \mu \mathrm{l})$ were analyzed (after reduction) by SDS-PAGE ( $7.5 \%$ gel) with silver staining. The samples analyzed were the initial reaction mixture $(A)$, the flow-through $(B)$, and two washes $(2 \mathrm{ml}$ each) consisting of the following solutions: $0.15 \mathrm{M} \mathrm{NaCl}$ in HT (C, D); $10 \mathrm{mM} p$-nitrophenyl $\alpha$-D-galactopyranoside in HT (E, F); $10 \mathrm{mM}$ DLphosphothreonine in HT $(\mathrm{G}, \mathrm{H}) ; 10 \mathrm{mM}$ DL-phosphoserine in HT (I, J); and $10 \mathrm{mM}$ potassium phosphate in HT $(K, L)$. The autophosphorylated form of the receptor was then eluted with five $2-\mathrm{ml}$ portions of 10 mM $p$-nitrophenyl phosphate in HT (M-Q). Finally, the column was washed with $2 \mathrm{ml}$ of $0.2 \mathrm{M}$ potassium phosphate, $\mathrm{pH} 7.5,0.1 \%$ Triton $\mathrm{X}-100(\mathrm{R})$. The arrows denote the migration position of $\beta$-galactosidase (116K), phosphorylase (94K), bovine serum albumin $(66 \mathrm{~K})$, and ovalbumin (45K). (A) Silver-stained gel; (B) autoradiogram of the same gel.

it directly to chemically activated Sepharose, we immobilized it by adsorption on protein A-Sepharose. This immobilization procedure not only effected further purification of the antibody by eliminating any non-IgG contaminants, but also yielded gels having a higher capacity to bind phos- 
phorylated insulin receptor than gels produced by reaction of the purified antibody with chemically activated Sepharose.

The silver-stained and autoradiographed SDS-PAGE gels depicted in Figs. 1A and $B$, respectively, illustrate noteworthy aspects of the chromatography of insulin receptor on immobilized $O$-phosphotyrosylbinding antibody. Lanes $A$ and $B$ of Fig. $1 \mathrm{~A}$ indicate that most of the protein applied to the Ab-protein A column was not adsorbed. Lanes E-J show that compounds having structural features in common with $p$-nitrophenyl phosphate such as $p$-nitrophenyl $\alpha$-D-galactopyranoside, $\mathrm{DL}-O$ phosphothreonine, and DL-O-phosphoserine failed (at concentrations of $10 \mathrm{~mm}$ ) to elute significant quantities of insulin receptor from the column. Phosphate ion at a concentration of $10 \mathrm{~mm}$, however, did elute a small amount of receptor from the column. Washes E-L of Fig. 1 were used to determine the specificity of elution with 10 mM $p$-nitrophenyl phosphate. These washes failed to remove nonreceptor protein from the column, and were omitted from subsequent chromatographic procedures (see Materials and Methods) with no decrease in product purity. The two major bands, at 125 and $95 \mathrm{kDa}$, shown in Fig. 1, lane M, are attributed to the $\alpha$ and $\beta$ subunits of the insulin receptor in the eluate from the Ab-protein A column. ${ }^{5}$ As expected when the WGA-purified insulin receptor was phosphorylated with $\left[\gamma^{32} \mathrm{P}\right] \mathrm{ATP}$, the mobility of the predominant species which was radiochemically labeled with ${ }^{32} \mathrm{P}$ corresponded to that of the $\beta$-subunit of the purified insulin receptor (Fig. 1B). ${ }^{5}$

The intact $\alpha_{2} \beta_{2}$ form of the receptor was eluted from the Ab-protein A column (with

\footnotetext{
${ }^{5}$ Close inspection of Fig. $1 \mathrm{~A}$ reveals barely detectable bands in the region of $50 \mathrm{kDa}$. These bands which become more prominent on overexposure to the silver stain are present when buffer is electrophoresed in the presence of thiols in the absence of receptor. Contamination by bacteria may be responsible for the appearance of these bands which have been reported by other investigators (25). Labeling of components in addition to the $95-\mathrm{kDa} \beta$ subunit is barely detectable in Fig. 1B. This labeling, however, corresponds to only a small fraction of the radiochemical label incorporated into the $\beta$ subunit.
}

$10 \mathrm{~mm} p$-nitrophenyl phosphate) in greater than $80 \%$ purity as judged from the relative intensities of the $370-$ and $320-\mathrm{kDa}$ bands produced by SDS-PAGE in the absence of reductant (Fig. 2). Overexposure of the gel in Fig. 2 to the silver stain resulted in a uniform increase in the intensity of the background with the appearance of no additional bands. When the WGA-purified receptor was phosphorylated in the presence of $\left[\gamma^{32} \mathrm{P}\right] \mathrm{ATP}$ and then chromatographed on $\mathrm{Ab}$-protein $\mathrm{A}$, the ${ }^{32} \mathrm{P}$ label was present in both the $370-$ and $320-\mathrm{kDa}$ proteins (Fig. 3, lane 2). The fact that little or no labeling of the $320-\mathrm{kDa}$ protein was seen immediately after the WGA-purified receptor was phosphorylated (Fig. 3, lane 1) suggests that the $320-\mathrm{kDa}$ protein was produced by proteolysis of intact receptor subsequent to phosphorylation. As expected, both the $320-$ and $370-\mathrm{kDa}$ proteins

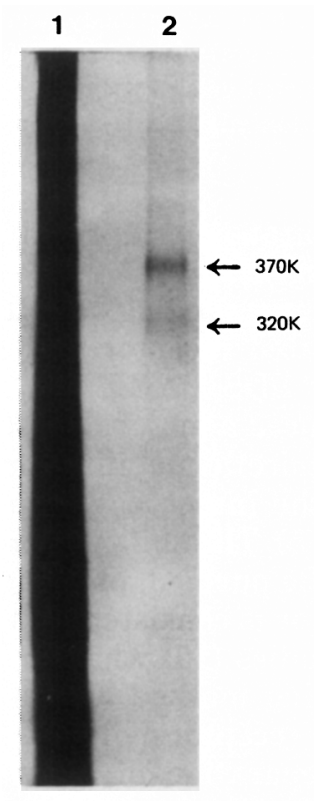

FIG. 2. SDS-PAGE of the insulin receptor before and after purification on immohilized $O$-phosphotyrosyl-binding antibody. After autophosphorylation, samples were subjected to SDS-PAGE (4.5\% gel) without reduction. Lane 1 is a sample of WGA-purified receptor that was applied to the immobilized antibody column. Lane 2 is a sample of the material eluted from the column by $10 \mathrm{mM} p$-nitrophenyl phosphate. Shown is a silver-stained gel. 


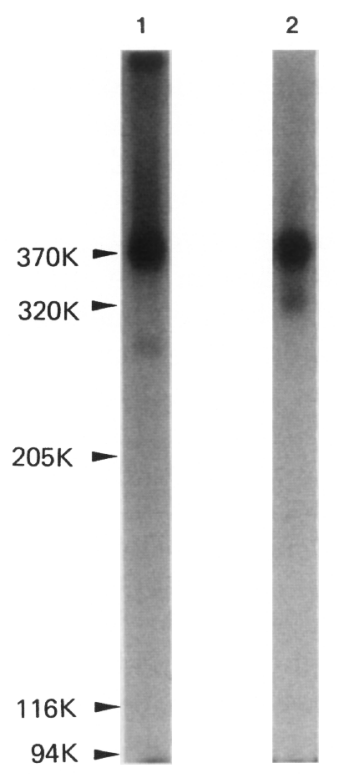

FIG. 3. Evidence for proteolysis during purification. WGA-purified receptor was phosphorylated in the

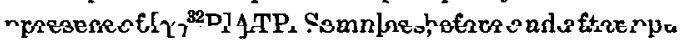
rification by chromatography on immobilized $O$ phosphotyrosyl-binding antibody, were analyzed by SDS-PAGE ( $4.5 \%$ gel) without reduction. Autoradiograms of the dried gels are shown. Lane 1, EDTAquenched reaction mixture; lane 2, purified receptor.

were precipitated by antibody to insulin receptor (Fig. 4).

Affinity crosslinking of the purified phosphorylated receptor with ${ }^{125} \mathrm{I}$-insulin followed by SDS-PAGE and autoradiography produced a major diffuse band with an electrophoretic mobility corresponding to that of the intact $\alpha_{2} \beta_{2}$ form of the receptor (Fig. 5). The ability to crosslink ${ }^{125} \mathrm{I}-$ insulin to the purified, phosphorylated insulin receptor is consistent with results of previous studies (10) wherein the doubleprobe labeling method was used to show that insulin receptor molecules in a WGApurified preparation of the receptor retained their competence to bind insulin after autophosphorylation. Comparison of lanes $A$ and $C$ of Fig. 5 reveals that the insulin-binding, fragmented forms of the receptor predominant in the WGA-purified receptor are almost eliminated by chromatography on immobilized $O$-phosphotyrosyl-binding antibody. The ability of this procedure to purify selectively the intact $\alpha_{2} \beta_{2}$ form of the insulin receptor is at- tributed to the fact that only the intact $\alpha_{2} \beta_{2}$ form undergoes insulin-promoted autophosphorylation during the brief treatment with ATP, and therefore only this form of the receptor is retained by the phosphotyrosine-binding antibody.

The 125:95 mass ratio of the $\alpha$ and $\beta$ subunits might be expected to produce an intensity ratio of about 1:0.76 in silverstained gels, provided that both subunits have a similar content of aminoacyl residues, which are responsive to the silver stain. An intensity ratio of 1:0.45 was observed, however, for the bands corresponding to the $\alpha$ and $\beta$ subunits. This result might be due to both a lower reactivity of the $\beta$ subunit toward the silver stain and a partial degradation of the $\beta$ subunit in the $320-\mathrm{kDa}$ minor component. Close examination of Fig. 1. lane M, reveals a minor band at $45 \mathrm{kDa}$ which is attributed to the fragmented $\beta$ chain of the $320-\mathrm{kDa}$ minor consonetic.

In an experiment designed to determine whether phosphorylated insulin receptor

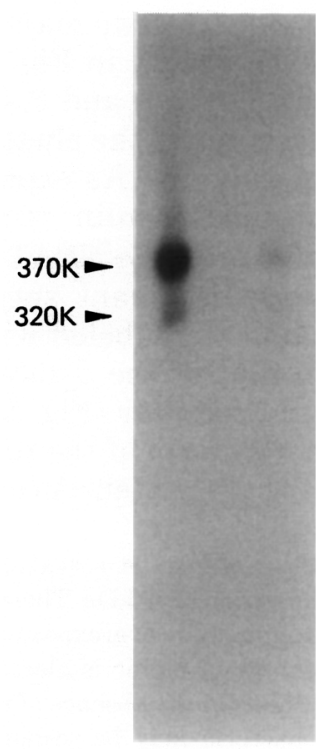

FIG. 4. Immunoprecipitation of purified insulin receptor purified by chromatography on Ab-protein A. Purified, ${ }^{32} \mathrm{P}$-labeled receptor was immunoprecipitated by an antireceptor antiserum (B-9). The immunoprecipitate (1) and supernatant (2) were analyzed by SDSPAGE (4.5\% gel) without reduction. Shown is an autoradiogram of the dried gel. 


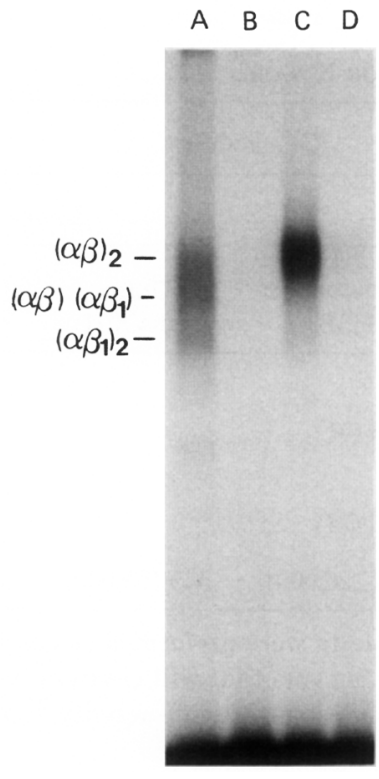

FIG. 5. Affinity crosslinking of insulin receptor before and after chromatography on Ab-protein A. WGA-purified receptor and receptor purified by chromatography on Ab-protein A were affinity-labeled with ${ }^{125} \mathrm{I}$-insulin (20 nM) and disuccinimidyl suberate $(0.3 \mathrm{mM})$, and electrophoresed in a $4.5 \% \mathrm{gel}$ in the absence of reductant. Shown is an autoradiogram of the dried gel. WGA-purified receptor $(14 \mu \mathrm{g})$ affinity-labeled with ${ }^{125} I$-insulin in the absence (A) and the presence (B) of unlabeled insulin $(0.2 \mu \mathrm{M})$. Receptor ( $50 \mathrm{ng}$ ) purified by chromatography on Ab-protein A was labeled in the absence (C) and the presence (D) of unlabeled insulin $(0.2 \mu \mathrm{M})$. The inhibition of crosslinking of ${ }^{125} \mathrm{I}$-insulin by excess unlabeled insulin shown in lanes $B$ and $D$ demonstrates the specificity of the affinity crosslinking. The electrophoretic mobilities of the $(\alpha \beta)_{2},(\alpha \beta)\left(\alpha \beta_{1}\right)$, and $\left(\alpha \beta_{1}\right)_{2}$ forms of insulin receptor correspond to those of proteins with $M_{\mathrm{r}}$ 's of $340 \mathrm{~K}, 320 \mathrm{~K}$, and $290 \mathrm{~K}$, respectively. Introduction of crosslinks has been shown (10) to decrease the electrophoretic mobility of insulin receptor and also to cause insulin receptor bands to become more diffuse (10). The presence of crosslinks, which probably prevent the protein from unfolding completely in SDS, are responsible for the reduction from $370 \mathrm{~K}$ (Fig. 2) to $340 \mathrm{~K}$ in the apparent $M_{\mathrm{r}}$ of the $(\alpha \beta)_{2}$ form of insulin receptor.

contained bound insulin after it had been purified by chromatography on Ab-protein A, WGA-purified insulin receptor was phosphorylated (with $\left[\gamma^{32} \mathrm{P}\right] \mathrm{ATP}$ ) using $\mathrm{N}^{\star \mathrm{B} 29}$-biotinylinsulin instead of insulin to promote receptor autophosphorylation. The resulting phosphorylated receptor was purified by chromatography on Ab-protein
$A$ in the usual manner, and immediately crosslinked with $0.3 \mathrm{~mm}$ disuccinimidyl suberate. The ${ }^{32} \mathrm{P}$-labeled, crosslinked insulin receptor was then subjected to SDSPAGE in the presence and absence of succinylavidin. The observation that succinylavidin did not alter the electrophoretic mobility of the ${ }^{32} \mathrm{P}$-labeled receptor indicated the absence of significant amounts of bound biotinylinsulin (data not shown). Control experiments wherein phosphorylated receptor was crosslinked in the presence of added $\mathrm{N}^{\mathrm{B} 29}$-biotinylinsulin yielded ${ }^{32} \mathrm{P}$-labeled, crosslinked receptor whose electrophoretic mobility was decreased by succinylavidin as previously reported (10).

A comparison of the kinase activity (toward histone $\mathrm{H} 2 \mathrm{~b}$ ) of the WGA-purified receptor and that of the intact phosphorylated receptor is shown in Fig. 6. In ad-

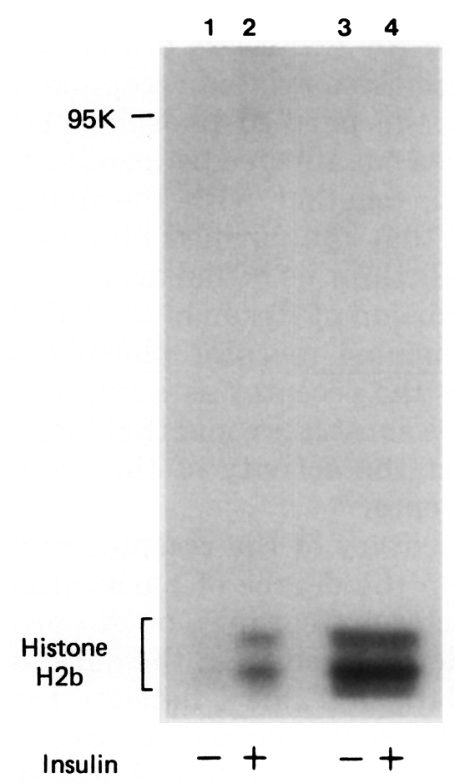

FIG. 6. Insulin-dependent phosphorylation of histone by phosphorylated receptor. Histone was phosphorylated by $14 \mu \mathrm{g}$ WGA-purified receptor (lanes 1 , 2) and $28 \mathrm{ng}$ phosphorylated receptor purified by chromatography on Ab-protein A (lanes 3,4 ) in the absence (lanes 1,3) and the presence (lanes 2, 4) of $0.63 \mu \mathrm{M}$ insulin as described under Materials and Methods. Shown is an autoradiogram of the dried gel. The appearance of two histone bands is attributed to the presence of histones $\mathrm{H} 2 \mathrm{a}$ and H2b. Protein-staining of this commercially obtained histone $\mathrm{H} 2 \mathrm{~b}$ also yielded two histone bands. 
TABLE I

Purification of the Insulin Receptor Kinase

\begin{tabular}{|c|c|c|c|c|c|}
\hline \multirow[b]{3}{*}{ Sample } & \multirow[b]{3}{*}{$\begin{array}{l}\text { Protein } \\
\text { (mg) }\end{array}$} & \multicolumn{4}{|c|}{ Kinase units } \\
\hline & & \multicolumn{2}{|c|}{ Assay I } & \multicolumn{2}{|c|}{ Assay II } \\
\hline & & $\begin{array}{l}\text { Angiotensin } \\
\text { II }\end{array}$ & $\begin{array}{l}\text { Histone } \\
\text { H2B }\end{array}$ & $\begin{array}{l}\text { Angio- } \\
\text { tensin II }\end{array}$ & $\begin{array}{l}\text { Histone } \\
\text { H2B }\end{array}$ \\
\hline $\begin{array}{l}\text { Phosphorylated WGA-purified } \\
\text { receptor }\end{array}$ & 20.7 & $1035(50)$ & $1056(51)$ & & \\
\hline $\begin{array}{l}\text { Ab-Protein A chromatog- } \\
\text { raphy flow-through }\end{array}$ & 20.7 & $435(21)$ & $435(21)$ & & \\
\hline Eluate & 0.0099 & $267(27,000)$ & $257(26,000)$ & $545(55,000)$ & $554(56,000)$ \\
\hline
\end{tabular}

dition to the increased kinase activity of the purified phosphorylated receptor (note the use of 500 times less protein with the purified phosphorylated receptor), the activity of the purified phosphorylated receptor was not affected by insulin. This observation, together with the findings indicating that the purified intact receptor contains little or no bound insulin, confirms the conclusion of Rosen et al. (26) that insulin-promoted receptor phosphorylation activates the receptor as a kinase toward exogenous substrates, and that insulin does not affect the activity of the phosphorylated receptor. ${ }^{6}$

The recovery of the receptor kinase activity and the degree of purification realized by chromatography on Ab-protein A can be determined from the data in Table I. The data in Table I indicate that only about $60 \%$ of the kinase activity was adsorbed on the Ab-protein A column. The inability to adsorb $100 \%$ of the kinase activity did not appear to be due to use of insufficient $A b$-protein $A$, as judged by the absence of significant quantities of phosphorylated insulin receptor in the flow-

\footnotetext{
6 This conclusion is further supported by the observation of Rosen et al (26) that alkaline phosphatase trcatment of partially purified phosphorylated insulin receptor restores the insulin sensitivity of the kinase activity.
}

through (Fig. 1B, lane B) and the observation that passage of the unadsorbed kinase over a regenerated column of $\mathrm{Ab}$ protein A failed to adsorb significant kinase activity. A substantial fraction of the unadsorbed kinase activity may reflect the presence of protein kinases which were not tyrosine-phosphorylated during the short ( $5 \mathrm{~min}$ ) incubation with ATP in the presence of insulin as well as incompletely phosphorylated insulin receptor. The data of Table I indicate that only 270 of the $\sim 600$ kinase enzyme units adsorbed on the Ab-protein A column were recovered as judged by direct assays of the kinase activity toward histone $\mathrm{H} 2 \mathrm{~b}$ and angiotensin II. This deficit in kinase units might be attributed in part to differences in the composition of the samples assayed or the presence of an activating factor in the WGA-purified receptor (or both), since assay of the eluate from the Ab-protein A column in the presence of the WGA-purified receptor (according to assay II wherein the activity of the added material was subtracted from the total activity) showed that greater than $90 \%$ of the $\sim 600$ kinase units adsorbed to the column was recovered in the eluate. The observation (data not shown) that bovine serum albumin is almost as effective as the WGA-purified receptor in assay II suggests, however, that most of the deficit in kinase units is due to 
losses of protein by adsorption on surfaces which often become significant in the transfer of dilute solutions of proteins. The ratio of the specific activities of the eluate and that of the WGA-purified antibody indicated that the chromatography of Abprotein A effected an approximately 500fold purification of insulin receptor kinase from human placenta. Purified insulin receptor was stored under liquid nitrogen, where its kinase activity remained unaltered for several weeks.

It is important to note that this purification procedure relies on specific autophosphorylation of the insulin receptor in the preparation of the WGA-purified receptor which had been passed through a column of Ab-protein A to adsorb any preexisting phosphotyrosyl-containing protein. Since the crude preparation may contain several receptor protein kinases and other proteins which might undergo tyrosyl phosphorylation upon incubation with ATP, care was taken to preincubate the preparation with insulin and quench the reaction $5 \mathrm{~min}$ after the addition of ATP. The degree of success of this approach is reflected in silver-stained and autoradiographed gels depicted in Figs. 14, which show that almost all of the purified material migrated in the positions expected for the insulin receptor and precipitated with antireceptor antibodies. Furthermore, the data in Table II indicate that anti-insulin receptor antibody precipitated $83 \%$ of the kinase activity of phosphorylated insulin receptor which had been purified by chromatography on Ab-protein A. This observation suggests that most, if not all, of the measured kinase activity is an integral part of the purified phosphorylated insulin receptor or tightly associated with it, and that if present, extraneous contaminating kinases are minor contributors $(\leqslant 17 \%)$ to the observed kinase activity. Thus, chromatography of insulin receptor on $O$-phosphotyrosyl-binding antibody immobilized on protein A-Sepharose appears to yield the catalytically active form of insulin receptor kinase. This material, which is nearly homogeneous, should be suitable for studies of the relationship between receptor structure and catalytic competence toward exogenous substrates. Studies of the insulin-promoted autophosphorylation event will, of course, require the unphosphorylated form of the receptor which is not directly obtained by the procedures described in the present paper.

Although the purification of insulin receptor by affinity chromatography on immobilized insulin and by chromatography on immobilized phosphotyrosyl-binding antibodies reported in this work yields different forms of the receptor, the latter procedure appears to offer some advantages over the former. The highest degree of purification of WGA-purified insulin receptor kinase has been obtained recently by Rosen and her co-workers (8), who made

TABLE II

IMMUNOPRECIPITATION OF RECEPTOR KINASE ACTIVITY WITH ANTIRECEPTOR ANTIBODY

\begin{tabular}{|c|c|c|c|c|}
\hline \multirow[b]{2}{*}{ Experiment } & \multirow[b]{2}{*}{ Receptor } & \multirow{2}{*}{$\begin{array}{c}\text { Protein } \\
\text { assayed } \\
\quad(\mu \mathrm{g})\end{array}$} & \multicolumn{2}{|c|}{ Kinase activity (cpm) } \\
\hline & & & Supernatant & Pellet \\
\hline 1 & $\begin{array}{l}\text { Phosphorylated WGA- } \\
\text { purified receptor }\end{array}$ & 23 & 9,828 & 14,161 \\
\hline 2 & $\begin{array}{l}\text { Ab-protein A-Sepharose } \\
\text { eluate }\end{array}$ & 0.048 & 4,710 & 22,759 \\
\hline
\end{tabular}

Note. Immunoprecipitation and kinase assays were carried out as described under Materials and Methods. The listed kinase activities (with histone $\mathrm{H} 2 \mathrm{~b}$ as substrate) were obtained by Cerenkov counting of the excised histone gel bands. The kinase activity listed for the supernatant is six times the observed incorporation of ${ }^{32} \mathrm{P}$ into histone to correct for the fact that only $1 / 6$ of the supernatant solution was assayed. Thus, $83 \%(22,759$ $\times 100 / 22,759+4,710)$ of the kinase activity of the purified receptor was precipitated by the anti-insulin receptor antibody. 
the important discovery that the presence of DTT during affinity chromatography markedly enhanced the specific activity of the recovered insulin receptor kinase. The WGA-purified insulin receptor kinase activity, however, could only be purified by 110- to 131-fold even in the presence of dithiothreitol. ${ }^{7}$ This purification factor is about 4-fold lower than that which we obtained by subjecting the WGA-purified receptor to chromatography on immobilized phosphotyrosyl-binding antibodies. ${ }^{8}$ The higher degree of purification obtained by chromatography on immobilized phosphotyrosyl-binding antibodies is attributed to the ability of this method to resolve the phosphorylated form of the receptor which is active as a kinase from the other (unphosphorylated) forms of insulin receptor which appear to be devoid of tyrosyl kinase activity.

\section{ACKNOWLEDGMENTS}

The assistance of Mr. Thomas Ling in the preparation of the WGA-purified insulin receptor from human placenta, and the assistance of Ms. Michelle Marceau in the assays of antibody titers, is gratefully acknowledged. The authors are also happy to acknowledge the cooperation of Dr. O. M. Rosen who made her work [Reference (8)] available to us prior to publication.

\section{REFERENCES}

1. Cuatrecasas, P. (1972) Proc. Nath Acad. Sci. USA 69, 1277-1281.

\footnotetext{
${ }^{7}$ It is important to note that the purification procedure reported in the present paper does not employ DTT, which in our hands results in partial reduction of interchain disulfide bonds in the receptor (unpublished observations).

${ }^{8}$ Differences in assay conditions and methods used to determine protein content make it difficult to compare absolute values of the final specific activity of insulin receptor obtained by the two methods of purification. However, the degree to which the WGApurified receptor is further purified by chromatography on immobilized insulin and immobilized phosphotyrosyl-binding antibodies can be estimated from the increases in specific activity effected by each procedure.
}

2. Jacobs, S., Shechter, Y., Bissell, K., ANd CuATRECASAS, P. (1977) Biochem. Biophysics Res. Commun. 77, 981-988.

3. HARRISON, L. C., AND ITIN, A. (1980) J. Biol Chem. 255, 12066-12072.

4. Heinrich, J., PILCh, P. F., AND CzECH, M. P. (1980) J. Biol. Chem. 255, 1732-1737.

5. Siegel, T. W., Ganguly, S., Jacobs, S., Rosen, O. M., AND RuBIN, C. S. (1981) J. Biol Chem. 256, 9266-9273.

6. Fujita-Yamaguchi, Y., ChoI, S., Sakamoto, Y., ITAKURA, K. (1983) J. Biol. Chem. 258, 5045-5049.

7. Fujita-YamaguChI, Y. (1984) J. Biol. Chem. 259, 1206-1211.

8. Petruzelli, L., Herrera, R., and Rosen, O. M. (1984) Proc. Natl. Acad. Sci. USA 81, 3327-3331.

9. Massague, J., Pilch, P. F., AND Czech, M. P. (1980) Proc. Natl. Acad. Sci. USA 77, 7137-7141.

10. Pang, D. T., Lewis, S. D., Sharma, B. R., AND ShaFer, J. A. (1984) Arch. Biochem. Biophys. 234, 629-638.

11. Shia, M. A., AND PILCH, P. F. (1983) Biochemistry 22, 717-721.

12. Hartman, F. C., Suh, B., Welch, M. H., and BarKER, R. (1973) J. Biol. Chem. 248, 8233-8239.

13. Ross, A. H., Baltimore, D., AND Eisen, H. N. (1981) Nature (London) 294, 654-656.

14. Rothrerg, P. G., Harris, T. J. R., Nomoto, A., AND Wimmer, E. (1978) Proc. Natl Acad. Sci. USA 75, 4868-4872.

15. FIELDS, R. (1972) in Methods in Enzymology (Hirs, C. H. W., and Timasheff, S. N., eds.), Vol. 25, pp. 464-468, Academic Press, New York.

16. HAwkES, R., NIDAY, E., AND GORDON, J. (1982) Anal. Biochem. 119, 142-147.

17. March, S. C., Parikh, I., and Cuatrecasas, P. (1974) Anul. Biochem. 60, 149-152.

18. MaRtensen, T. M. (1982) J. Biol Chem. 257, 96489652.

19. Pang, D. T., ANd Shafer, J. A. (1984) J. Biol. Chem. 259, 8589-8596.

20. Pang, D. T., AND ShaFer, J. A. (1985) J. Biol. Chem. 260, 5126-5130.

21. BRADFORD, M. M. (1976) Anal. Biochem. 72, 248254.

22. MoRRISSEY, J. H. (1981) Anal. Biochem. 117, 307310.

23. Stadtmauer, L. A., and Rosen, O. M. (1983) $J$. Biol. Chem. 258, 6682-6685.

24. LAEMMLI, U. K. (1970) Nature (London) 227, 680685.

25. Marshall, T., and Williams, K. M. (1984) Anal. Biochem. 139, 502-505.

26. Rosen, O. M., Herrera, R., Olowe, Y., PetruzELli, L. M., AND CoBB, M. H. (1983) Proc. Nath Acad. Sci. USA 80, 3237-3240. 